Louisiana State University

LSU Digital Commons

July 2019

\title{
Sodium-Ion Concentration Flow Cell Stacks For Salinity Gradient Energy Recovery: Power Generation Of Series And Parallel Configurations
}

Elizabeth Whiddon

Follow this and additional works at: https://digitalcommons.Isu.edu/gradschool_theses

Part of the Environmental Engineering Commons

\section{Recommended Citation}

Whiddon, Elizabeth, "Sodium-Ion Concentration Flow Cell Stacks For Salinity Gradient Energy Recovery: Power Generation Of Series And Parallel Configurations" (2019). LSU Master's Theses. 4983. https://digitalcommons.Isu.edu/gradschool_theses/4983

This Thesis is brought to you for free and open access by the Graduate School at LSU Digital Commons. It has been accepted for inclusion in LSU Master's Theses by an authorized graduate school editor of LSU Digital Commons. For more information, please contact gradetd@lsu.edu. 


\title{
SODIUM-ION CONCENTRATION FLOW CELL STACKS FOR SALINITY GRADIENT ENERGY RECOVERY: POWER GENERATION OF SERIES AND PARALLEL CONFIGURATIONS
}

\author{
A Thesis \\ Submitted to the Graduate Faculty of the \\ Louisiana State University and \\ Agricultural and Mechanical College \\ in partial fulfillment of the \\ requirements for the degree of \\ Master of Science in Civil Engineering \\ in
}

The Department of Civil and Environmental Engineering

by

Elizabeth Whiddon

B.S, The University of Michigan, 2015

August 2019 


\section{TABLE OF CONTENTS}

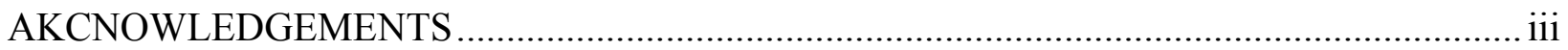

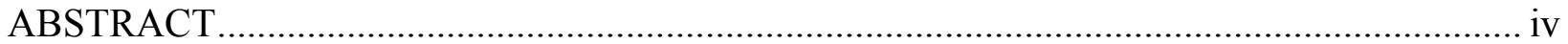

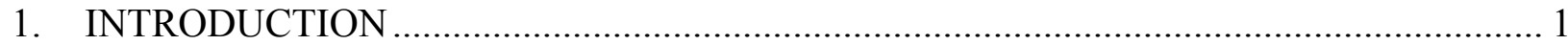

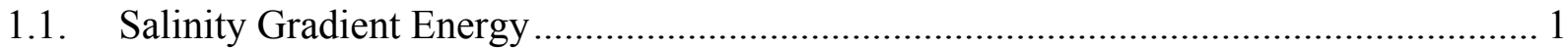

1.2. Overview of Existing Salinity Gradient Energy Technologies ........................................ 1

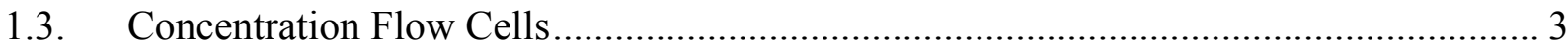

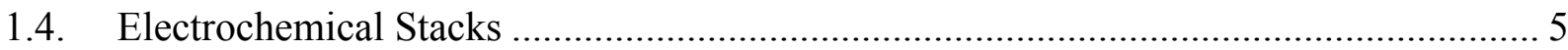

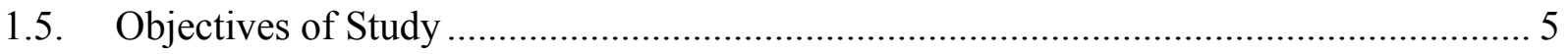

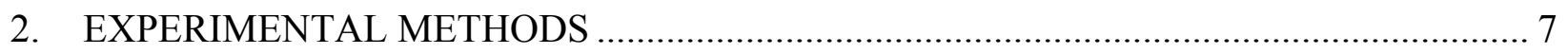

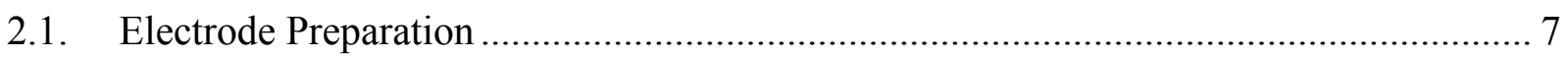

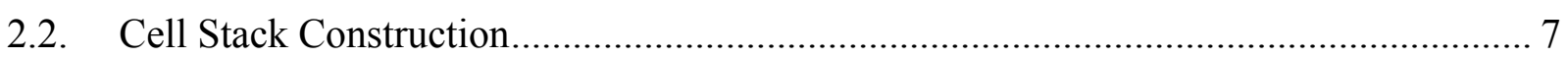

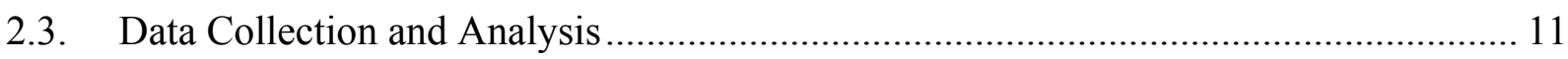

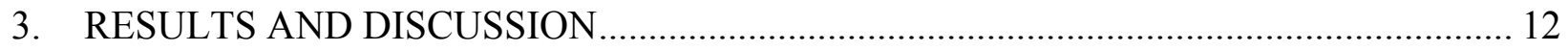

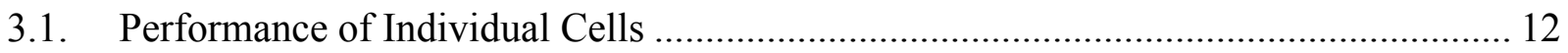

3.2. Performance of Parallel Wire Configuration ............................................................ 13

3.3. Performance of Series Wire Configuration.............................................................. 16

3.4. Parallel and Series Performance Comparison .............................................................. 20

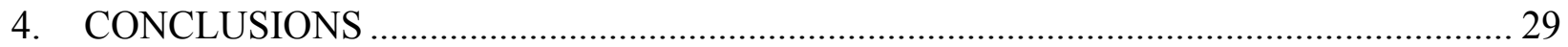

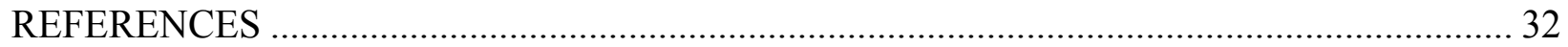

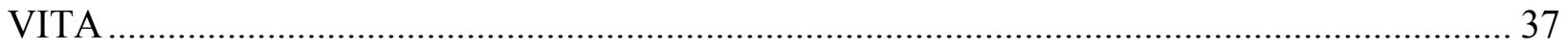




\section{ACKNOWLEDGMENTS}

I would like to express my sincere gratitude to my advisor, Dr. Xiuping Zhu, who provided knowledge, patience, and never ending support. Her confidence in me is what brought me to Louisiana State University, and without her I would not be here. I would also like to thank my thesis committee, Dr. Chris Arges and Dr. Frank Tsai, for providing their time, and supporting me throughout my research. Lastly, I would like to thank my lab group, Sidan Lu, Guangcai Tan, and Haihui Zhu, and Mechanical Engineering PhD candidate, Arash Pourbagheri Jirandehi. My research would not have been possible without their willingness to help, and I am truly grateful to have worked with them. 


\section{ABSTRACT}

Salinity gradient (SG) energy is a renewable and clean energy resource that exists worldwide from the change in Gibbs free energy when two solutions with different salinities are mixed. More recently, concentration flow cells (CFCs) have been introduced as a new technology for SG energy recovery with the highest reported power density output to date, as a result of the utilization of both the electrode potential and Donnan potential. In this study, multiple CFCs were connected to form a consecutive number of stacks, and systematic analysis was conducted to investigate the influence of both parallel and series electrical wire connections on the overall performance. For both wire connections, an effective increase in the overall power output with an increase in stack size was observed. The power densities normalized to the membrane area were however lower $\left(3.7 \mathrm{~W} \mathrm{~m}^{-2}\right.$ in series and $5.8 \mathrm{~W} \mathrm{~m}^{-2}$ in parallel, for 5- stacks) than the individual cell unit $\left(8.9 \mathrm{~W} \mathrm{~m}^{-2}\right)$ because of the cumulative mixing towards the back of the stack. Additionally, as a result of an ionic cross-conduction causing a parasitic current in the series cell, the parallel wire configuration was demonstrated to be more successful in the CFC stack than the series. 


\section{INTRODUCTION}

\subsection{Salinity Gradient Energy}

As a result of the continuous increase in population, the worldwide energy demand is set to grow by more than $25 \%$ to 2040 [1]. This need for new energy supply along with the observed changes in climate from fossil fuel combustion has encouraged the use of alternative and sustainable energy resources [2]. Salinity gradient (SG) energy, or the free energy that results from the mixing of waters with different salinity concentrations (e.g., seawater and river water), is an attractive form of renewable energy due to the lack of fossil fuel dependency and also the preexisting natural salinity gradients that occur at costal river deltas. This energy source, estimated to contain 625 TWh of practical energy discharging every year, can supply $3 \%$ of the worldwide electricity consumption [3]. In addition, there are numerous sources of saline water that could be exploited at industrial sites (e.g., agro-food, petroleum, leather) to improve economic efficiency and sustainability, and even larger energy density sources can be found from waters that have salt concentrations higher than that of seawater (e.g., hydraulic fracturing flowback, desalination plants, hypersaline lakes) [4-8].

\subsection{Overview of Existing Salinity Gradient Energy Technologies}

Several techniques have been investigated for converting SG energy into power, and most of which can be classified into two categories, membrane-based and electrode-based technologies. One membrane-based technology that has received the most attention to date (with subsequent pilot-plants) is pressure retarded osmosis (PRO). In PRO, while seawater and river water are separated by a semi-permeable membrane, the chemical potential gradient causes the river water to be transferred by osmosis across the membrane into the pressurized seawater. The osmotic pressure is then converted to hydraulic head as a result of the water transport [9-13]. Although the 
measured power density of PRO is high for SG energy technologies (7.1 $\mathrm{W} \mathrm{m}^{-2}$-membrane area) [14], susceptibility to membrane fouling and the relatively short membrane life restricts efficient performance and limits PRO from being a cost competitive system [13,15,16,17].

Reverse electrodialysis (RED) systems are recognized as another membrane-based technique because they primarily develop cell voltages from the Donnan potential that arises when ions are transported across membranes. In RED, ion-exchange membranes are stacked in a repeated array. Seawater and river water are then fed through alternated anion- and cationexchange membranes with a cascade, continuous flow design [18-20]. By stacking multiple membranes, the electrical potential can be built up and then converted into electron flow when two electrodes are positioned on each side of the stack. Similarly to PRO, RED systems have reached the pilot phase, however the highest reported power output of traditional RED systems is $1.5 \mathrm{~W}$ $\mathrm{m}^{-2}$ [21]. Because the ion-exchange membranes are the most expensive component in RED systems, an economic assessment has determined that for RED to be considered economically viable, a power density of $\geq 2 \mathrm{~W} \mathrm{~m}^{-2}$ is needed [22]. However, because the working principle in RED is limited by the dilute channel resistance, improving the membranes (e.g., increasing the membrane conductivity) does not necessarily increase the power output of RED systems [22]. To fully utilize the stacked membranes in RED, operating each individual membrane with a successive electrode pair could potentially increase the power output and further improve the economic efficiency.

Capacitive Mixing (CapMix) systems are electrode-based techniques that develop a potential as a result of electrochemical interactions at electrode-water interfaces [23-27]. One type of CapMix technique, Mixing Entropy Batteries, stores ions in the electrode material's bulk crystal structure and behaves as a reversible electrochemical system [28]. When the system is flushed with 
river water and sweater, the battery will charge and discharge (based on the electrode material) as a result of the electrode storing and releasing specific ions. Capacitive Double Layer Expansion (CDLE) is another type of CapMix system in which the electrodes are charged with seawater to establish the electric double layer (EDL) [23]. The cell's voltage is increased by expanding the EDL when the electrodes are brought into contact with river water, and the electrodes are then discharged through an external load. Although CapMix technologies are attractive due to their use of low cost carbon electrodes, the power output of these technologies is still an order of magnitude lower than membrane-based technologies such as RED and PRO [26].

\subsection{Concentration Flow Cells}

More recently, the highest maximum power density for SG energy technologies (12.6 W $\mathrm{m}^{-2}$-membrane area) was achieved using a sodium-ion concentration flow cell (CFC) with two copper hexacyanoferrate electrodes (CuHCF) and an anion-exchange membrane (AEM) [29]. In a sodium-ion CFC, two identical electrodes with two flow channels are positioned on each side of an ion-exchange membrane (Figure 1.1.). Synthetic seawater $\left(30 \mathrm{~g} \mathrm{~L}^{-1} \mathrm{NaCl}\right)$ and freshwater $(1 \mathrm{~g}$ $\left.\mathrm{L}^{-1} \mathrm{NaCl}\right)$ are separately and simultaneously fed into the cell. A Donnan potential $\left(E_{d}\right)$ develops as $\mathrm{Cl}^{-}$-ions are transported across the ion-exchange membrane from the $\mathrm{HC}$ solution to the $\mathrm{LC}$ solution. At the same time, an electrode potential $\left(E_{e}\right)$ develops at the CuHCF electrodes from the $\mathrm{Fe}^{2+} / \mathrm{Fe}^{3+}$ redox pair, which is driven by $\mathrm{Na}^{+}$intercalating on the cathode and deintercalating on the anode. The linkage between the potentials and the activity $(a)$ of participants involved is described in the following Nernst equations:

$$
\begin{aligned}
& E_{d}=\frac{R T}{n F} \ln \left(\frac{a_{C l-, \mathrm{HC}}}{a_{C l-, \mathrm{LC}}}\right) \\
& E_{e}=\frac{R T}{n F} \ln \left(\frac{a_{N a+, \mathrm{HC}}}{a_{N a+, \mathrm{LC}}}\right)
\end{aligned}
$$


where $n$ is the number of electrons passed, $F$ is the Faraday constant $\left(96485 \mathrm{C} \mathrm{mol}^{-1}\right), R$ is the gas constant $\left(8.314 \mathrm{~J} \mathrm{~mol}^{-1} \mathrm{~K}^{-1}\right)$, and $T$ is the absolute temperature $(298 \mathrm{~K})$.

When the solutions with an existing chemical gradient are directed through the flow channels, the cell is charged as ions transport within the cell to maintain electroneutrality. When the solutions are switched, the chemical gradient is reversed and the cell is then recharged. Because the CFC simultaneously develops both a Donnan potential and electrode potentials, the theoretical reversible potential $\left(E_{\text {cell }}\right)$ of the CFC can be written as the sum of each potential as follows:

$$
E_{\text {cell }}=E_{d}+E_{e}
$$

The success of the CFC and the notable high power output is therefore ultimately the result of the utilization of both potentials in the same cell.

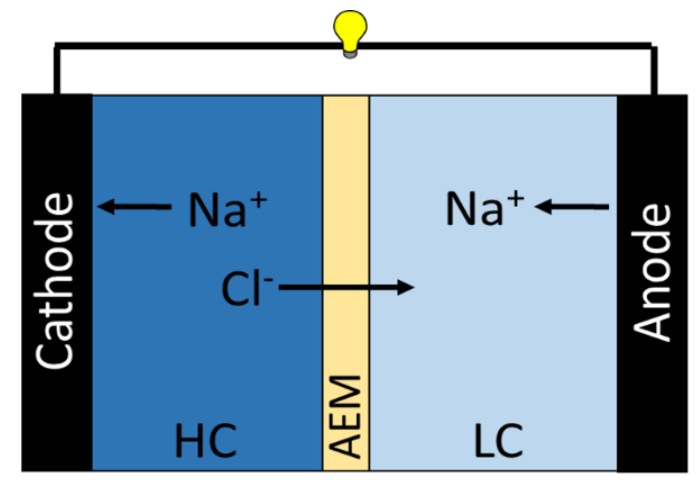

Figure 2.2. The 5-stack CFC used in this study with five cell units, two endplates, and sealed with nuts and bolts. Inflow channels are on the left and outflow channels are on the right.

Other hexacyanoferrate electrode materials similar to CuHCF (e.g., NiHCF, $5.1 \mathrm{~W} \mathrm{~m}^{-2}$; MnHCF, $430 \mathrm{~mW} \mathrm{~m}^{-2}$; and $\mathrm{ZnHCF}, 30 \mathrm{~mW} \mathrm{~m}^{-2}$ ) have also been demonstrated to work in a sodiumion CFC using the same working principle [30]. More recently, alternative CFC systems with different designs have also been investigated. For example, a chloride-ion CFC consisting of a cation-exchange membrane (CEM) and metal chloride electrodes was shown to develop electrode potentials from $\mathrm{Cl}^{-}$extraction and insertion (as opposed to $\mathrm{Na}^{+}$intercalation/deintercalation) [31]. 
Furthermore, a capacitive CFC with a maximum power density of $5.3 \mathrm{~W} \mathrm{~m}-2$ was developed to utilize the CDLE of carbonized peat moss electrodes in combination with a CEM [32].

\subsection{Electrochemical Stacks}

In order to increase the cell power in RED technologies, multiple membranes are stacked in one cell. Similarly, a multi-stack design is also implemented in other electrochemical technologies. Perhaps the most commonly recognized electrochemical stack is a Polymer Electrolyte Membrane Fuel Cell (PEMFC) in which multiple membrane electrode assemblies are stacked to increase the potential and power output of the cell [33]. Other examples of electrochemical stacks include Microbial Fuel Cell (MFC) [34] stacks and Redox Flow Battery (RFB) stacks.

Stacked cells can be electrically connected in a number of different ways depending on what parameter (i.e., voltage or current) is targeted for a higher operating value [36]. In theory, cells connected in series increase the voltage whereas cells connected in parallel increase the current. If a higher operating voltage, power, and current density is desired, the cells can be wired in both parallel and series. In addition to the different wire configurations, different flow configurations can also be employed in electrochemical stacks [37]. In a series hydraulic flow design, also referred to as a continuous cascade flow design, the solution enters one cell and then proceeds continuously through the consecutive cells. In a parallel hydraulic flow design the solution enters each individual cell separately.

\subsection{Objectives of Study}

Here, we stacked a maximum of five CFCs using a repeated array of CuHCF electrodes and anion-exchange membranes. By using a serial hydraulic flow design similar to that of an RED cell, each cell in the stack could simultaneously recharge and further produce power when the 
solution flow paths were periodically switched. We investigated the performance of various sized CFC stacks (1-5) by consecutively adding cell units together and show an almost linear increase in the power with an increase in stack size. Additionally, we examined the influence of parallel and series circuit configurations on the overall performance of the stack and further note a performance loss in the series stack as a result of a parasitic current. These results are the first indepth analysis that we know of for a CFC stack using different circuit configurations and a continuous flow. As renewable energy becomes more desirable and the pursuit of cost-effective SG technologies continues, implications reported in this study will be useful for successfully designing CFC stacks for efficient power production. 


\section{EXPERIMENTAL METHODS}

\subsection{Electrode Preparation}

CuHCF was synthesized by a co-precipitation method [38,39]. Two solutions, $80 \mathrm{~mL}$ of $0.1 \mathrm{M} \mathrm{Cu}\left(\mathrm{NO}_{3}\right)_{2}$ (Sigma-Aldrich) and $80 \mathrm{~mL}$ of $0.05 \mathrm{M} \mathrm{K}_{3}\left[\mathrm{Fe}(\mathrm{CN})_{6}\right]$ (J.T.Baker), were combined in constant ratios by simultaneous dropwise addition to deionized water $(40 \mathrm{~mL})$ under vigorous stirring at room temperature. The resulting orange-brown mixture was centrifuged, and the collected precipitates were washed and further dried overnight in a drying vacuum oven at $70{ }^{\circ} \mathrm{C}$. The electrode powder was then made with $\mathrm{CuHCF}(70 \mathrm{wt} \%)$ and carbon black $(20 \mathrm{wt} \%$, conductive carbon, Alfa Aesar, 99.5\%) and ground using a mortar and pestle. The binder was made using 2.5\% polyvinylidene fluoride (PVDF, Alfa Aesar) dissolved in $0.5 \mathrm{~mL}$ dimethylformamide (Alfa Aesar, 99\%). The binder (10 wt $\%)$ was then mixed with the electrode powder $(90 \mathrm{wt} \%)$ to make the final electrode slurry. Carbon paper was activated (in a $1 \mathrm{M} \mathrm{HCl}$ solution overnight), washed, and dried, and the electrode slurry was then hand painted in a $1 \mathrm{~cm} \times 3 \mathrm{~cm}\left(\mathrm{ca} .3 \mathrm{~cm}^{2}\right)$ rectangle on both sides of carbon paper. The electrodes were dried overnight in a vacuum oven at $70^{\circ} \mathrm{C}$ and rinsed before use.

\subsection{Cell Stack Construction}

All experiments were performed in a custom-built cell stack that consisted of five individual CFC units (Figure 2.1). Each cell unit contained an anion-exchange membrane (Selemion AMV, Asahi Glass, Japan) with two identical CuHCF electrodes positioned on each side of the membrane (total of 10 electrodes and 5 membranes). Individual silicon gaskets (127 $\mu \mathrm{m})$ were cut in such a way that the electrodes could be placed in the middle so to avoid leakage and to hold the electrodes in place. Short platinum wires $(2.5 \mathrm{~cm})$ were used as current leads for each electrode. The position of the electrodes was altered in each cell unit (e.g., a cathode of one 
cell was positioned beside the cathode of the neighboring cell so that the flow channel could be shared). At both ends of the stack, two Perspex plates $(5 \mathrm{~cm} \times 5 \mathrm{~cm} \times 3 \mathrm{~mm})$ with a thicker solid silicon gasket $(5 \mathrm{~cm} \times 5 \mathrm{~cm} \times 508 \mu \mathrm{m})$ on the inside of each plate were placed and sealed used using rods and nuts (Figure 2.2).

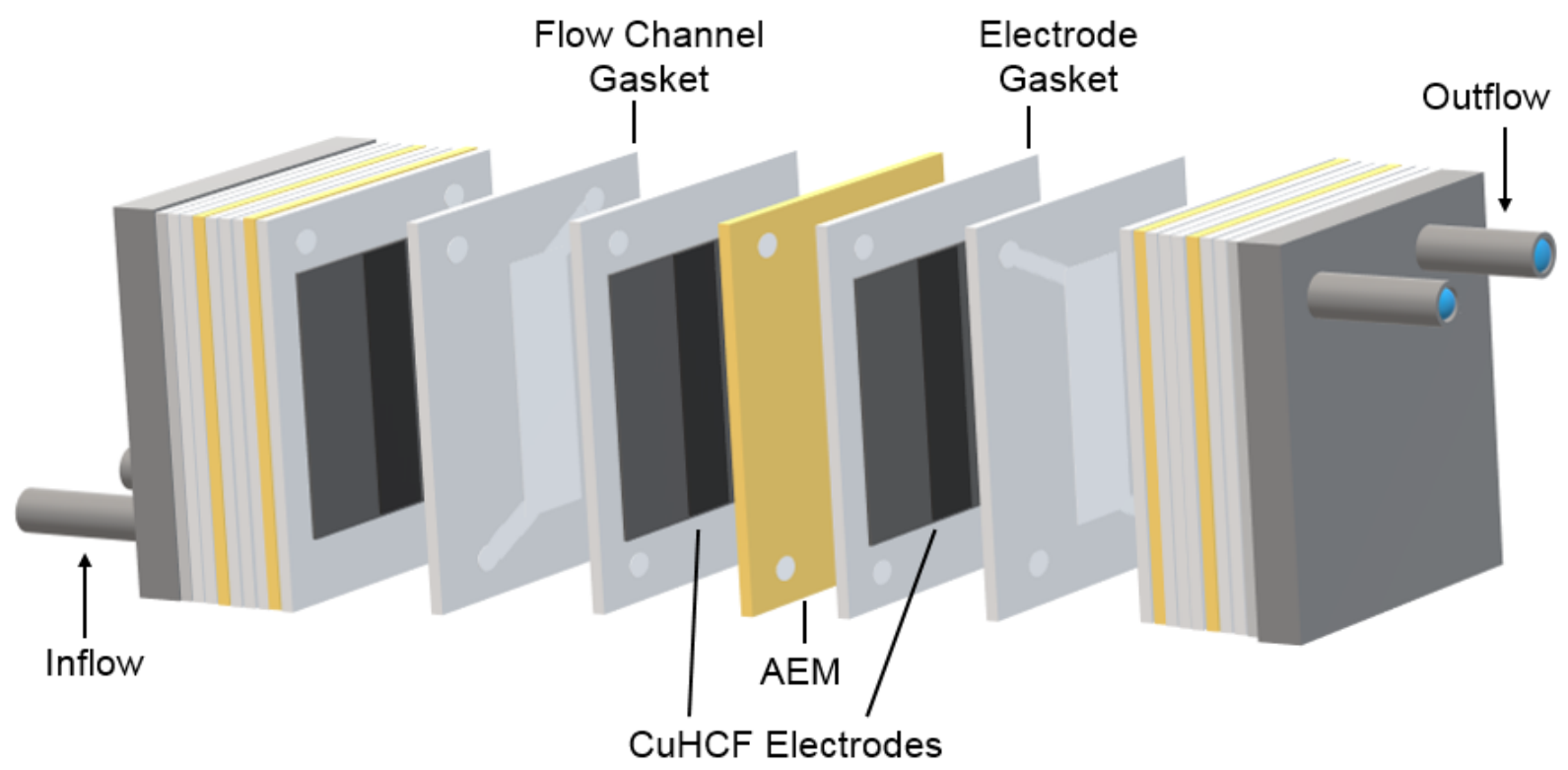

Figure 2.1. Representative figure of the 5-stack CFC configuration including five AEMs (yellow), ten gaskets holding ten $\mathrm{CuHCF}$ electrodes (black), and six gaskets for flow channels (light gray). 


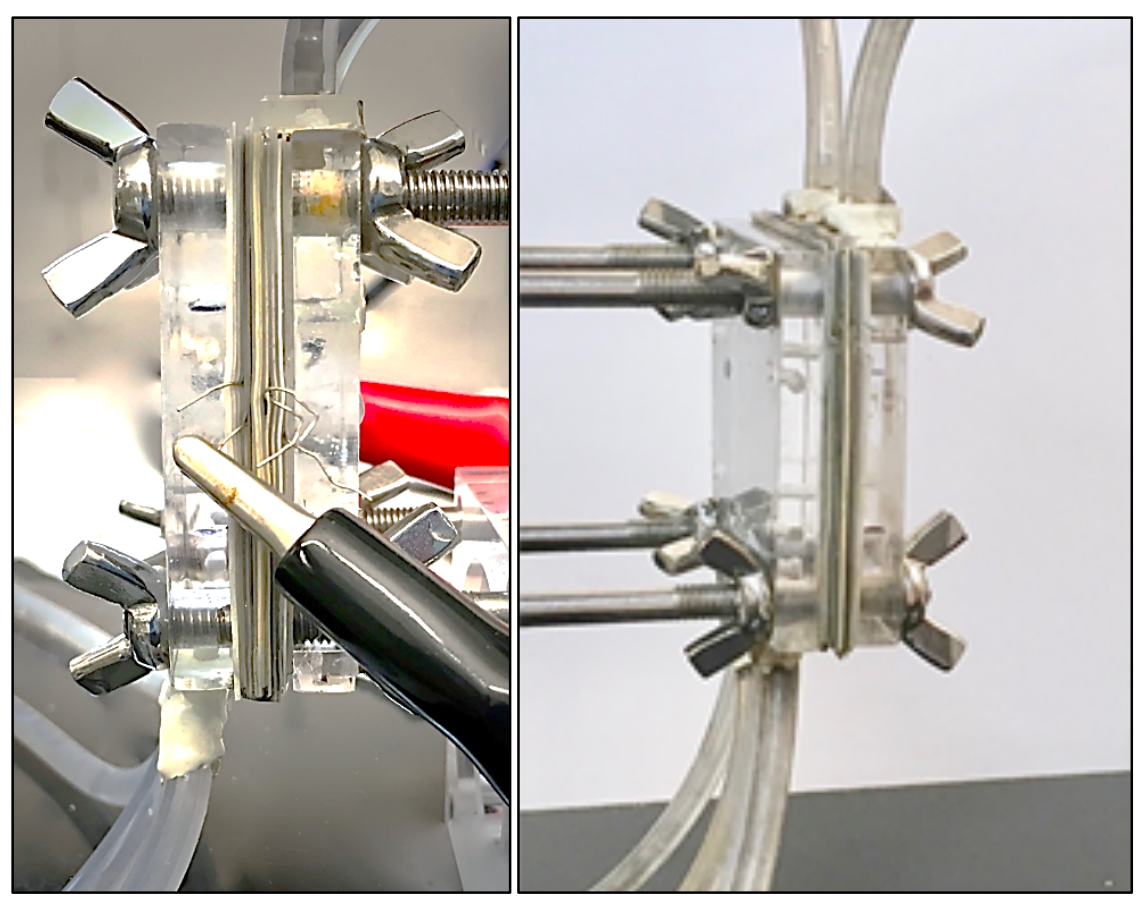

Figure 2.2. The 5-stack CFC used in this study with five cell units, two endplates, and sealed with nuts and bolts. Inflow channels are on the left and outflow channels are on the right.

Flow channels $(3 \mathrm{~cm} \times 1 \mathrm{~cm} \times 127 \mu \mathrm{m})$ made from silicon gasket were positioned on the back of each electrode and shared between neighboring cell units. This design allowed for a more compact reactor with only six flow channels as well as to prevent membrane fouling and deformation [40]. Two inlets with flow channels were installed on the front plate and two outlet flow channels were installed on the back plate. Two partitions, one for a high concentration (HC, $30 \mathrm{~g} \mathrm{~L}^{-1} \mathrm{NaCl}$ ) solution and one for a low concentration (LC, $1 \mathrm{~g} \mathrm{~L}^{-1} \mathrm{NaCl}$ ) solution, were constructed consecutively in each cell compartment to implement a serial hydraulic flow (Figure 2.3). This was done by installing two holes for the two solutions and aligning them in each subsequent cell compartment. As the two solutions simultaneously flowed through the holes along the hydraulic path, one solution was directed through the $3 \mathrm{~cm} \times 1 \mathrm{~cm}$ rectangular flow channel, while the other solution was separately directed to the following flow channel (on the other side of the membrane) and vice versa so that the solutions flowed continuously in the stack. 


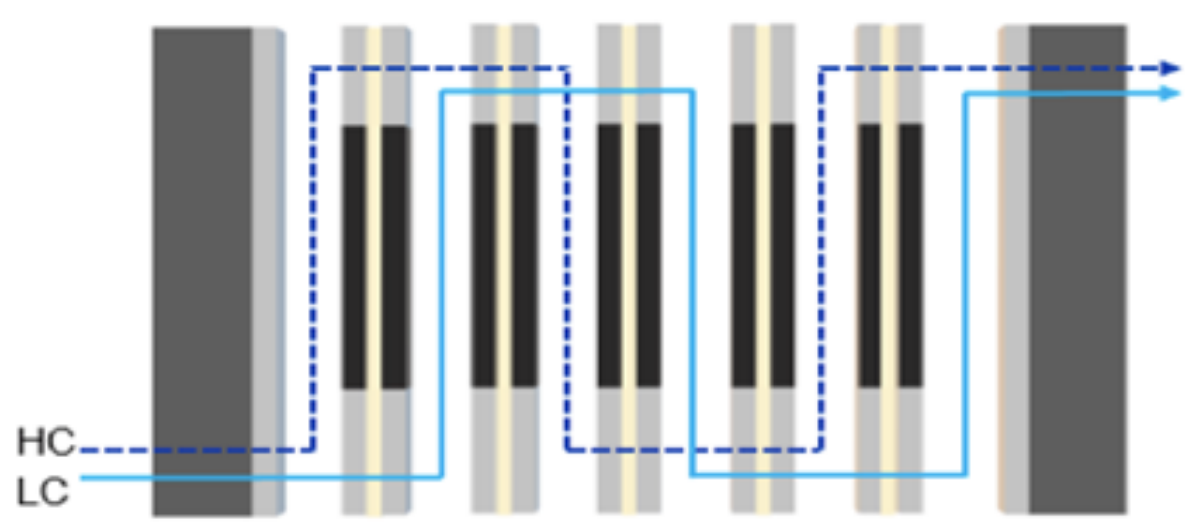

Figure 2.3. Schematic figure of the serial hydraulic flow.

To electrically connect the stacks in series and parallel, the platinum wires placed on each electrode were carefully attached externally using metal clips (Figure 2.2, 2.4). Experiments for both series and parallel configurations were performed in increasing order of stack starting with the first individual cell unit and ending with all five cell units electrically connected to form the 5stack. It should be noted that although the stacks are labeled as 1-5 throughout the paper, the first stack is truly just an individual CFC cell unit. The cell was dissembled only after the experiments for all five stacks were complete.

(a)

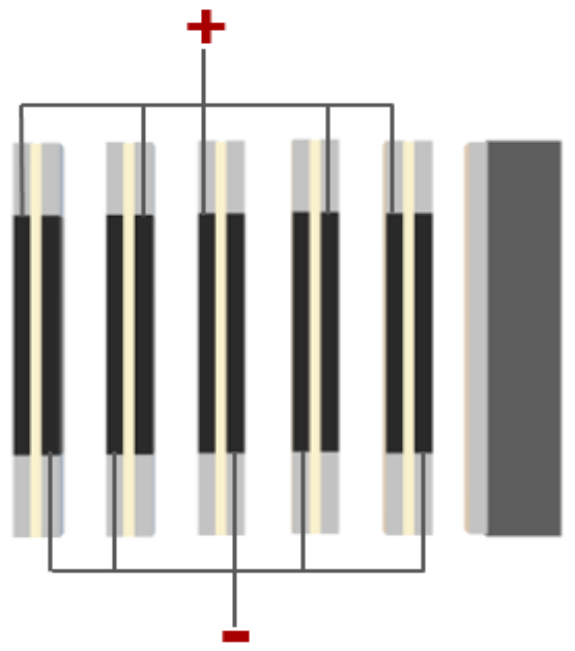

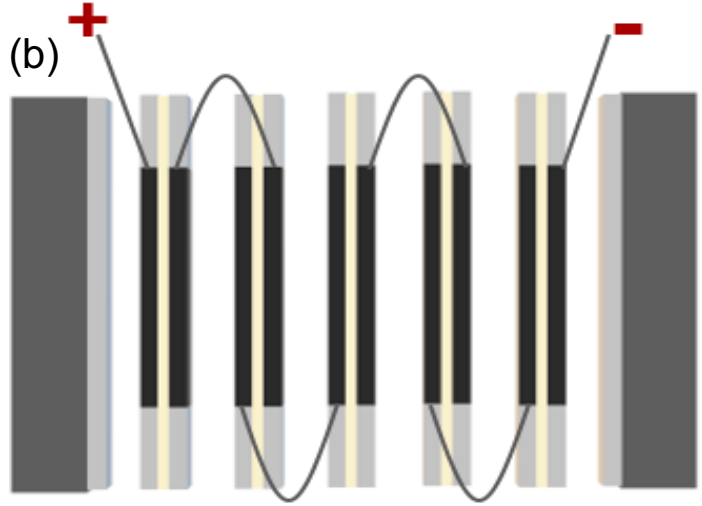

Figure 2.4. (a) Wire configuration of the parallel stack, and (b) wire configuration of the series stack. 


\subsection{Data Collection and Analysis}

The stacks were continuously supplied with the HC solution (representative of seawater) and the LC solution (representative of river water) using a peristaltic pump (Cole-Parmer) at a flow rate of $14 \mathrm{~mL} \mathrm{~min}^{-1}$ to assure no leakage. Open circuit voltages (OCVs) of the stacks were recorded using a potentiostat (VMP3, Bio-Logic) and HC and LC solutions were switched once the OCVs reached a stabilized value. External resistors $\left(\mathrm{R}_{\mathrm{ext}}\right)$ were connected to each stack and the power was calculated from the recorded voltage $(\mathrm{U}$, in $\mathrm{V})$ by the potentiostat and the $\mathrm{R}_{\text {ext }}(\mathrm{P}=$ $\left.\mathrm{U}^{2} / \mathrm{R}_{\mathrm{ext}}\right)$. When the cell voltage reached below a cutoff voltage of $8 \mathrm{mV}$, the solutions were switched and a new cycle began.

The $R_{\text {ext }}$ was varied in attempt to achieve impedance-matching $\left(R_{\text {ext }}=R_{\text {int }}\right)$ in which the maximum power was transferred to the external load (i.e., Maximum Power Transfer (MPT) point). The MPT of each individual cell unit was first analyzed in order to assure that the cells were functioning properly. The total theoretical resistance for each stack in parallel and series was calculated using the $\mathrm{R}_{\mathrm{ext}}$ of the individual cell units at MPT. A range of $\mathrm{R}_{\mathrm{ext}}$ around the calculated theoretical resistance was then applied to each stack until the true MPT of each stack was found.

The power density was calculated for each stack by dividing the power by the total membrane area $\left(3 \mathrm{~cm}^{2}\right.$ for 1 -stack, $6 \mathrm{~cm}^{2}$ for 2 -stacks, $9 \mathrm{~cm}^{2}$ for 3 -stacks, $12 \mathrm{~cm}^{2}$ for 4 -stacks, and $15 \mathrm{~cm}^{2}$ for 5 -stacks). The energy density was calculated by integrating the power density over one cycle, and the average power density was calculated by dividing the energy density by the cycle time. During analysis, a single cycle was calculated beginning with the switch of solutions and ending with when the power reached to $0.25 \mathrm{~mW}$. All tests were performed at ambient room temperature. 


\section{RESULTS AND DISCUSSION}

\subsection{Performance of Individual Cells}

After the stack was assembled, the power output for all five individual cells was examined before the cells were electrically connected in order to assure that each cell was working. Although a slight variation in the performance of each cell unit could be expected (e.g., due to the variation in electrode or membrane performance), a clear trend in the variation of performance of each cell unit was observed from the front to the back of the stack. The current and voltage that was recorded at each peak power showed a steady decrease along the hydraulic path which resulted in the peak power of the last cell to be less than half of the first cell $\left(9.3 \mathrm{~W} / \mathrm{m}^{2}, 6.6 \mathrm{~W} / \mathrm{m}^{2}, 5.7 \mathrm{~W} / \mathrm{m}^{2}, 4.5 \mathrm{~W} / \mathrm{m}^{2}\right.$, 3.7 W/m², for cell units $1-5$, respectively) (Table 3.1 ).

This similar trend in performance has also been observed in RED technologies that operate with a serial flow as a result of unwanted mixing. When a cascade design is used, irreversible mixing occurs in the consecutive cell compartments. That is, as the solutions move from the first cell to the last cell, the $\mathrm{NaCl}$ concentration decreases in the $\mathrm{HC}$ solution and increases in the $\mathrm{LC}$ solution. The cumulative decrease in the concentration gradient of the two solutions changes the thermodynamic potential for each cell unit. This results in the reduction of the power output.

To determine if cumulative mixing between the HC and LC solutions was the cause of the decrease in the individual cell's power densities, the conductivities of the solutions at the inflow and outflow of the cell were measured. The ion activities found from these measurements were then used to calculate the theoretical cell voltage at the front and back of the cell. The theoretical voltages showed a considerable decrease from $0.3 \mathrm{~V}$ (first cell unit) to $0.25 \mathrm{~V}$ (last cell unit) that corroborates the observed reduction in power density from the front of the cell to the back. It is not clear whether this mixing was a result of the physical limitations of the cell (i.e., flow channel 
design, membrane performance), or rather an intrinsic characteristic of cascade designed stacks in which ionic species are most efficiently utilized in the first cell, and consequentially the electroactive charges in the feed solutions are altered along the flow path.

Table 3.1. The peak power density $\left(\mathrm{P}_{\max }\right)$ with the corresponding voltage, current, and external resistance at the peak power for each individual cell unit.

\begin{tabular}{|c|c|c|c|c|}
\hline $\begin{array}{c}\text { Individual } \\
\text { Cell Unit }\end{array}$ & $\begin{array}{c}\mathrm{P}_{\max } \\
\left(\mathrm{W} \mathrm{m}^{-2}\right)\end{array}$ & $\begin{array}{c}\mathrm{U} \\
(\mathrm{mV})\end{array}$ & $\begin{array}{c}\mathrm{I} \\
(\mathrm{mA})\end{array}$ & $\begin{array}{c}\mathrm{R}_{\text {ext. }} \\
(\Omega)\end{array}$ \\
\hline 1 & $9.3 \pm 2.3$ & $151 \pm 4$ & $16 \pm 1$ & 9 \\
\hline 2 & $6.6 \pm 0.6$ & $127 \pm 8$ & $15 \pm 1$ & 9 \\
\hline 3 & $5.7 \pm 0.5$ & $122 \pm 8$ & $14 \pm 1$ & 9 \\
\hline 4 & $4.5 \pm 0.6$ & $108 \pm 10$ & $12 \pm 1$ & 9 \\
\hline 5 & $3.7 \pm 0.6$ & $99 \pm 8$ & $11 \pm 1$ & 9 \\
\hline
\end{tabular}

\subsection{Performance of Parallel Wire Configuration}

After estimating the individual power output of each cell unit, the stack was electrically connected in parallel and the OCV was measured. In theory, as explained in section 1.4, the voltage of a battery wired in parallel is expected to be maintained between each component. The stack connected in parallel behaved as predicted, and the OCV values for all stacks were similar (ca. \pm $0.155 \mathrm{~V})$. This was consistent with the theoretical voltage that was calculated from the Nernst equation (equation 1,2) for both the Donnan potential across the ion-exchange membrane $(\sim 0.08$ V) and the electrode potential $(\sim 0.08 \mathrm{~V})$, as well as with previously reported OCV values $[29,30]$ derived from an individual $\mathrm{CuHCF}$ concentration flow cell using solutions with the same $\mathrm{NaCl}$ concentration (Figure 3.1). 


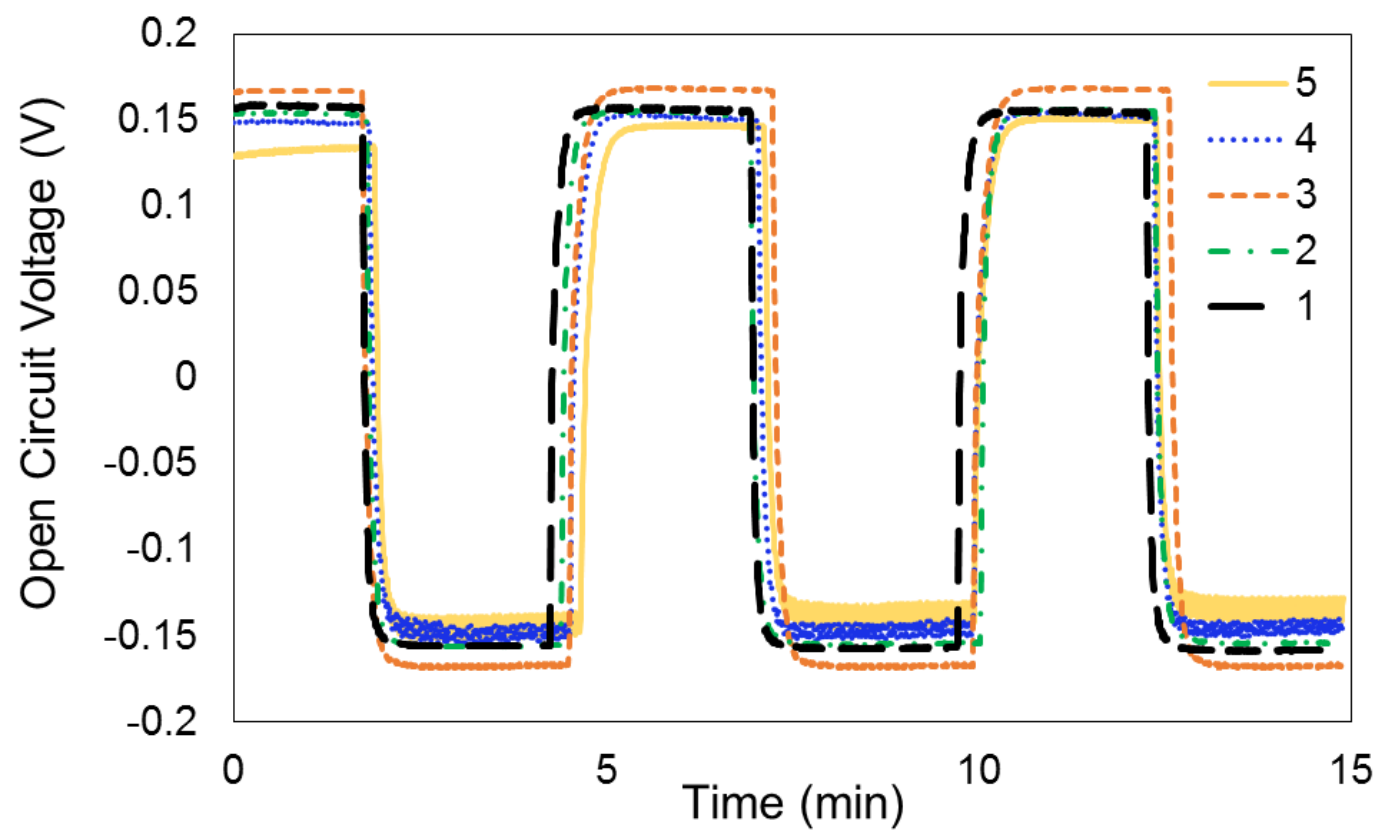

Figure 3.1. Open circuit voltages for 1-5 stacks connected in parallel.

The peak power of the stacks connected in parallel showed an almost linear increase with the increase of stack size $(2.8 \mathrm{~mW}, 5.3 \mathrm{~mW}, 7.1 \mathrm{~mW}, 7.5 \mathrm{~mW}, 8.6 \mathrm{~mW}$ for stacks 1-5, respectively), with a peak power for the 5 -stack being three times as high as that achieved for the single cell (Figure 3.2a). A similar trend was observed with a smaller rate of increase for the average power ( $1 \mathrm{~mW}, 1.6 \mathrm{~mW}, 2 \mathrm{~mW}, 2.1 \mathrm{~mW}, 2.5 \mathrm{~mW}$ for stacks 1-5, respectively) (Figure 3.2a). This substantially less gain in the average power was due to the exponential discharging trend of a cycle, which resulted in the average power to be more heavily weighted by the lower values of the cycle. 

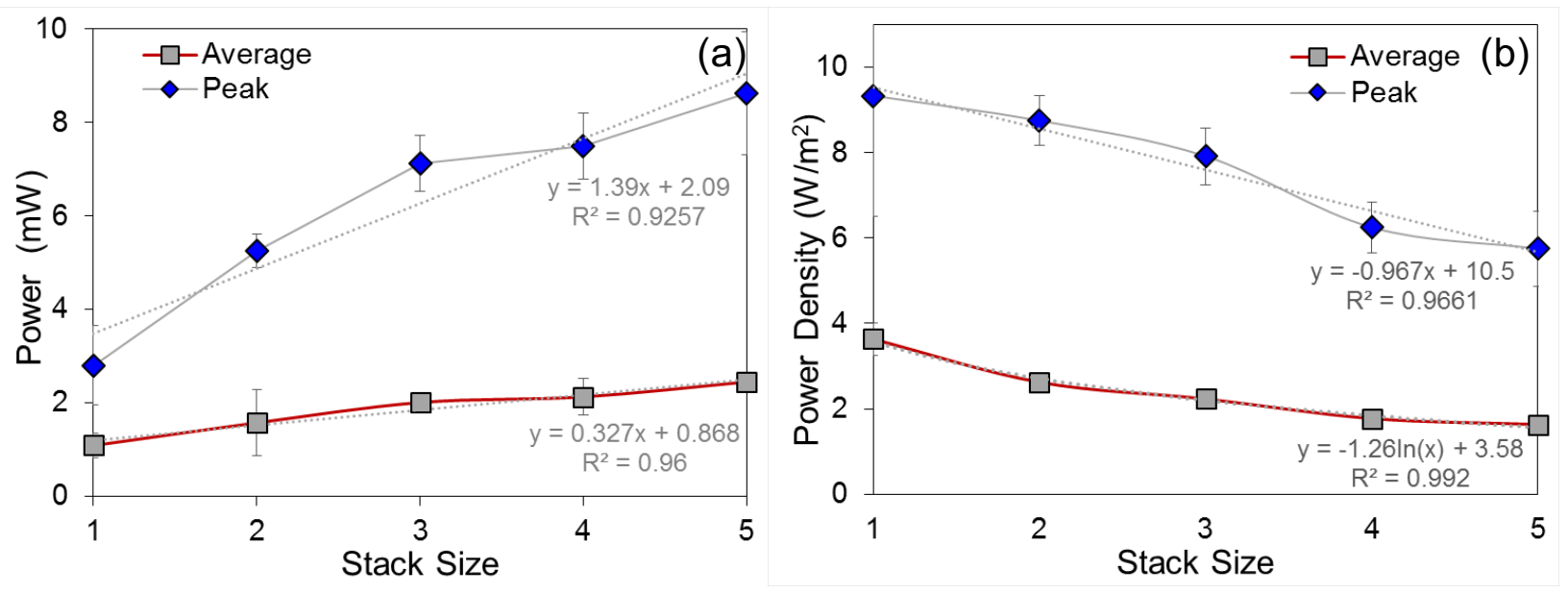

Figure 3.2. (a) Peak power and average power, and (b) peak power density and average power density for stacks 1-5 connected in parallel.

As alluded to previously, the most expensive component of the concentration flow cell is the ion-exchange membrane. Therefore, power densities normalized by the active membrane area must be evaluated in order to consider the economic viability. The peak power density of the stacks wired in parallel decreased with an increase in stack size $\left(9.3 \mathrm{~W} / \mathrm{m}^{2}, 8.6 \mathrm{~W} / \mathrm{m}^{2}, 7.9 \mathrm{~W} / \mathrm{m}^{2}, 6.3\right.$ $\mathrm{W} / \mathrm{m}^{2}, 5.8 \mathrm{~W} / \mathrm{m}^{2}$, for stacks $1-5$, respectively) (Figure $3.2 \mathrm{~b}$ ). A similar decreasing trend was also observed for the individual cell units in which the power density of each cell unit decreased from the front to the back of the stack when they were tested before electrically connecting them together (section 3.1, Table 3.1). The decrease in power densities in the parallel stacks was therefore not a result of the parallel connection, but rather it was a direct consequence of the serial flow design causing unwanted mixing. Because the individual cell units could not maintain a power density equivalent to that of the first cell unit, the stacked cells were also unsuccessful in maintaining a constant power density and therefore displayed a similar consecutive decrease.

The average power density for the stacks wired in parallel also decreased with an increase in stack size $\left(3.6 \mathrm{~W} / \mathrm{m}^{2}, 2.6 \mathrm{~W} / \mathrm{m}^{2}, 2.3 \mathrm{~W} / \mathrm{m}^{2}, 1.8 \mathrm{~W} / \mathrm{m}^{2}, 1.6 \mathrm{~W} / \mathrm{m}^{2}\right.$, for stacks $1-5$, respectively) as seen in Figure 3.2b, however the trend appeared to be more logarithmic. This was due to the steady 
increase in the stack's active membrane area while the average power nominally increased. That is, there was a 5 -fold increase in the active-membrane area of the 5 -stack but only a 2.5 -fold increase in the average power.

\subsection{Performance of Series Wire Configuration}

After completing the experiments for the stack wired in parallel, the stack was assembled using new electrodes and membranes and the electrical connection was switched to a series configuration. In theory, when a battery is wired in series, the voltage increases while the current is maintained. Like most fuel cells and batteries that are stacked together, a series wire connection is desirable due to the said voltage increase and further increase in power production. Here, we show that the series configuration did not perform as predicted and rather exhibited severe performance degradation in comparison to both the single cell and parallel stack.

The evidence of the performance loss in the series stack was first observed from the voltage drop in the OCVs (Figure 3.4). When the HC and LC solutions were switched at the inlet to initiate onset of OCV measurement, the voltage quickly reached a peak and then exponentially decreased to reach a stabilized value for both positive and negative cycles. Furthermore, unlike the OCVs of the parallel stacks, which stabilized almost immediately after switching solutions, the OCVs of the series stacks took approximately 15-20 min. to stabilize. 


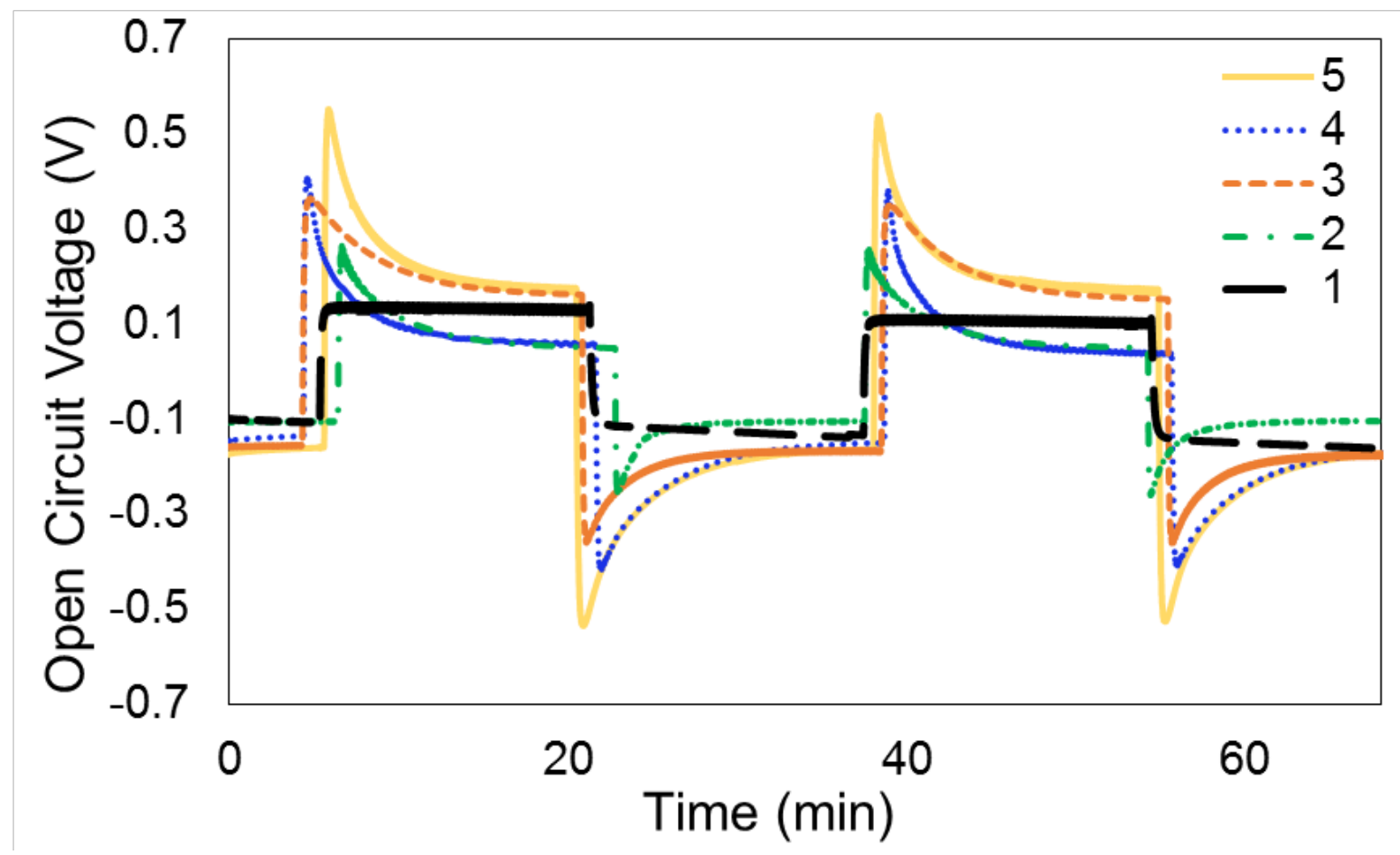

Figure 3.3. Open circuit voltages for 1-5 stacks connected in series.

As expected the peak voltages did in fact increase with an increase in stack size, however after stabilizing, the values all fell within the same, consistently low range (Figure 3.5). The overall change in voltage (from the peak to the stabilized value) became more pronounced with an increase in stack size (Figure 3.3). Additionally, the stabilized OCV of the 5-stack (0.15 V) and the 3-stack $(0.16 \mathrm{~V})$ were only somewhat higher than the OCV of the single cell $(0.13 \mathrm{~V})$, and the 2-stack $(0.09 \mathrm{~V})$ and the 4-stack (0.10) were actually lower (Figure 3.4). 


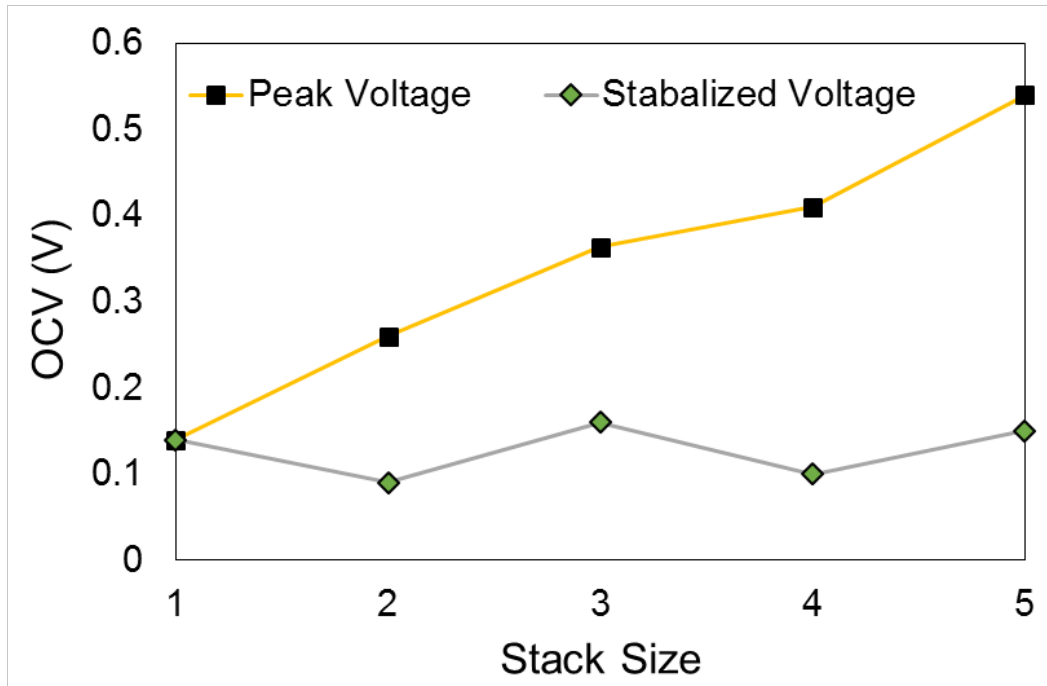

Figure 3.4. Open circuit voltage peak and stabilized value for 1-5 stacks connected in series.

This voltage loss phenomenon has previously been observed in fuel cell arrays that are hydraulically and electrically connected in series and has been linked to ionic cross-conduction in the electrolyte causing a parasitic current, or leakage current in the cell [41-46]. When two cells are connected in series, the electrons that are charged at the anode of the first cell are transferred through the external wire to the cathode of the neighboring cell. In order to maintain electroneutrality, ions then concurrently travel through the conductive electrolyte as a parasitic current to complete the circuit (Figure 3.5). This results in an internal, parasitic cell that adversely affects the stack voltage. Because no external current can flow through the cell during OCV, the open cell voltage drop is a solid indication of the existence of a parasitic current. Similarly, parasitic currents are known to occur in RED cells in the drain and feed channels (termed ionic shortcut currents) [47]. 


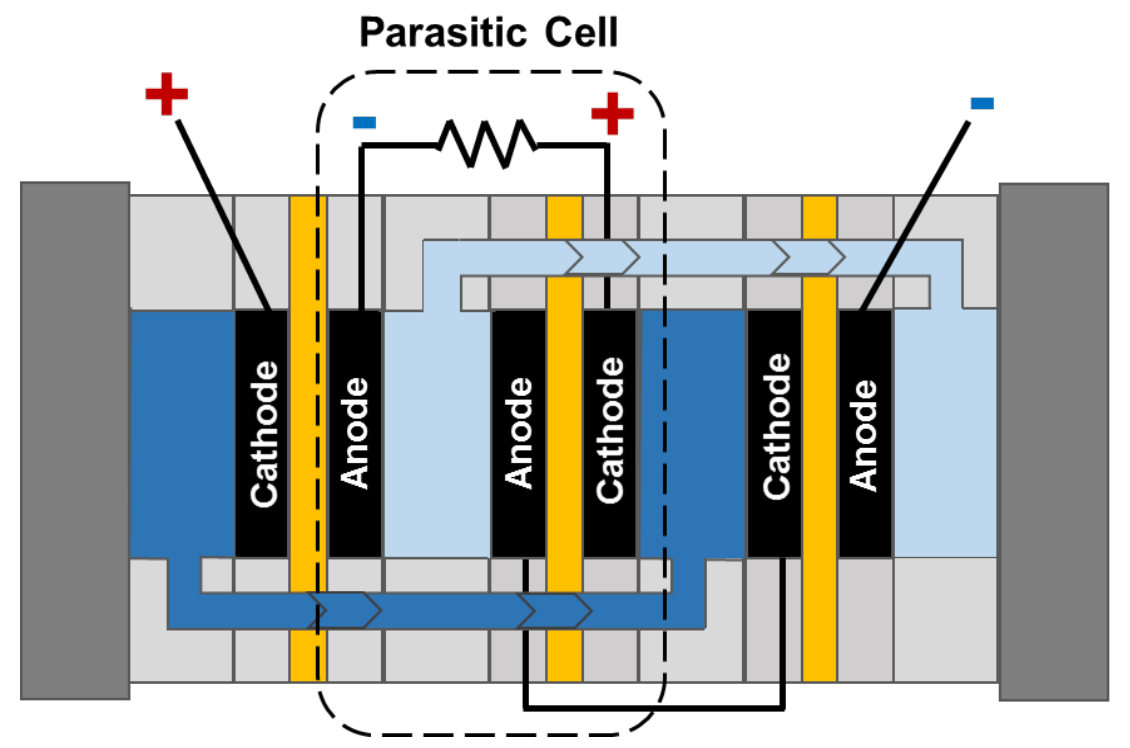

Figure 3.5. Illustration of ionic cross-conduction in the first two neighboring cells of a 3-stack connected in series.

The peak power $(2.5 \mathrm{~mW}, 3.7 \mathrm{~mW}, 4.3 \mathrm{~mW}, 4.9 \mathrm{~mW}, 5.6 \mathrm{~mW}$ for stacks 1-5, respectively) and average power ( $1 \mathrm{~mW}, 1.2 \mathrm{~mW}, 1.3 \mathrm{~mW}, 1.6 \mathrm{~mW}, 1.7 \mathrm{~mW}$ for stacks 1-5, respectively) for the stacks wired in series followed a similar trend to the parallel stack, with an almost linear increase with an increase in stack size (Figure 3.6a). The average power increased at a much smaller rate again as a result of the exponentially decreasing trend of a cycle. Additionally, the peak power density $\left(8.4 \mathrm{~W} / \mathrm{m}^{2}, 6.2 \mathrm{~W} / \mathrm{m}^{2}, 4.8 \mathrm{~W} / \mathrm{m}^{2}, 4 \mathrm{~W} / \mathrm{m}^{2}, 3.7 \mathrm{~W} / \mathrm{m}^{2}\right.$, for stacks $1-5$, respectively) and average power density $\left(3.2 \mathrm{~W} / \mathrm{m}^{2}, 2 \mathrm{~W} / \mathrm{m}^{2}, 1.5 \mathrm{~W} / \mathrm{m}^{2}, 1.3 \mathrm{~W} / \mathrm{m}^{2}, 1.1 \mathrm{~W} / \mathrm{m}^{2}\right.$, for stacks 1-5, respectively) could not improve with the addition of stack size in series (Figure 3.6b). This was due to the diminished performance of the individual cell units from the front to the back of the stack, as was explained previously for the parallel wire connection (Table 3.1). 

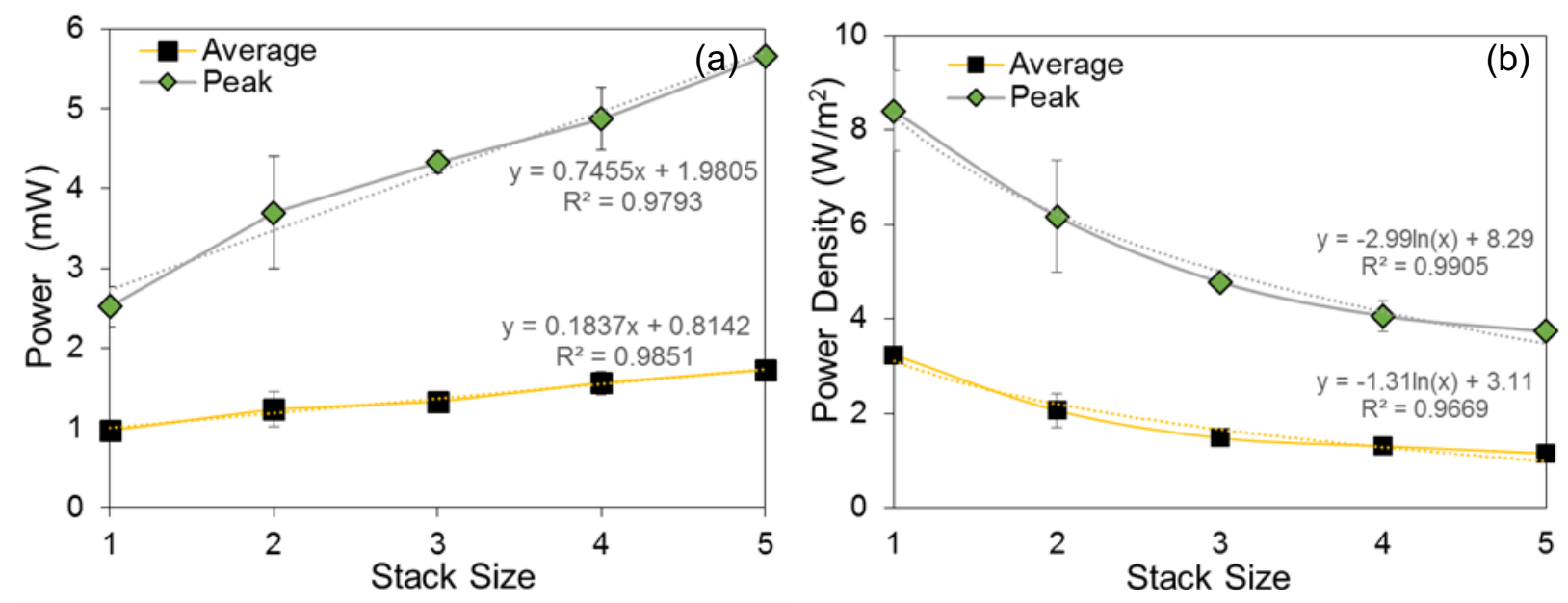

Figure 3.6. (a) Peak power and average power, and (b) peak power density and average power density for stacks $1-5$ connected in series.

\subsection{Parallel and Series Performance Comparison}

\subsubsection{Power Output}

Although the trends in the power output for the parallel and series stacks was similar, the two wire connections demonstrated a distinctive difference in performance. The series stack exhibited a severe performance degradation, which resulted in the power output of the 5-stack to be only slightly higher than that of the parallel 2-stack (Figure 3.7). For both the parallel and series stacks, the peak power and average power linearly increased with an increase in stack size, however the average rate of increase for the parallel stack was almost two times that of the series stack. This suggests that significant energy losses occurred as a result of the series connection, and further increasing the stack size would only add to these energy losses. 

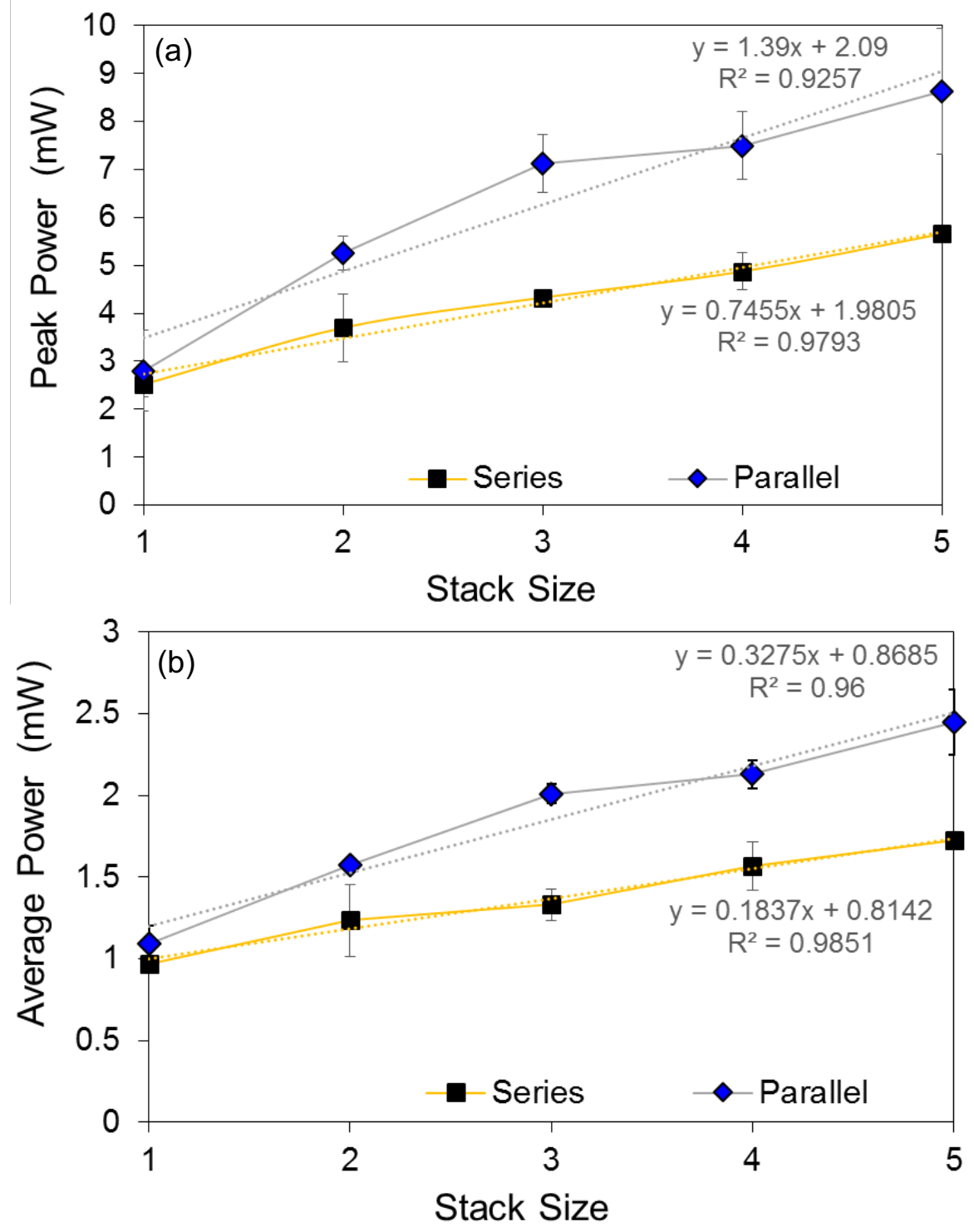

Figure 3.7. (a) Peak power and (b) average power for stacks 1-5 connected in parallel and series.

Another detrimental phenomenon that is commonly reported in serially stacked fuel cells is the occurrence of voltage reversal. In the past, voltage reversal was believed to be a result of fuel starvation [48], however in more recent years it has been confirmed that the root cause of the reversal in MFCs is due to the kinetic imbalance between connected cells [49,50]. For that reason, when excess current is drawn (e.g., at a current above the inferior cell's limiting current density), an inferior cell will likely reverse polarity due to the slow kinetics [51]. Voltage reversal is 
therefore generally observed at low resistances (high current densities) [48,52]. In this study, the $\mathrm{R}_{\text {ext }}$ was only applied in a range for the purpose of finding the maximum power output (as opposed to developing a complete polarization curve). Therefore, because the $\mathrm{R}_{\mathrm{ext}}$ was never lowered to a value that corresponded to any of the cell's limiting current densities (Table 3.1), it is unlikely that a voltage reversal was observed during our analyses.

Furthermore, if one of the cells that was added to the stack was suffering from a voltage reversal, then the measured voltage at that stack size would not increase (or surpass the voltage of the lesser stack) as there would be no input of additional voltage. In fact, a voltage reversal would adversely lower the stack's overall voltage, resulting in a decrease in voltage with an increase in stack size. Nevertheless, this was not the case and the stack voltage (measured at the peak power) did increase with the increase in stack size (Table 3.2). Therefore, it is considered that a voltage reversal did not occur in the series CFC stacks and instead the observed performance degradation was only a consequence of the parasitic current. 
Table 3.2. The peak power density $\left(\mathrm{P}_{\max }\right)$ with the corresponding voltage, current, and external resistance at the peak power for each stack 1-5 in parallel and series.

\begin{tabular}{|c|c|c|c|c|c|}
\hline \multirow{2}{*}{$\begin{array}{c}\text { Wire } \\
\text { Configuration }\end{array}$} & $\begin{array}{c}\text { Stack } \\
\text { Size }\end{array}$ & $\begin{array}{c}\mathrm{P}_{\max } \\
\left(\mathrm{Wm}^{-2}\right)\end{array}$ & $\begin{array}{c}\mathrm{U} \\
(\mathrm{m} V)\end{array}$ & $\begin{array}{c}\mathrm{I} \\
(m A)\end{array}$ & $\begin{array}{c}\mathrm{R}_{\text {ext. }} \\
(\Omega)\end{array}$ \\
\hline \multirow{4}{*}{ Parallel } & 1-stack & $9.3 \pm 2.8$ & $166 \pm 9$ & $17 \pm 2$ & 9 \\
\cline { 2 - 6 } & 2-stack & $8.8 \pm 0.6$ & $145 \pm 7$ & $38 \pm 6$ & 4 \\
\cline { 2 - 6 } & 3-stack & $7.9 \pm 0.7$ & $146 \pm 2$ & $48 \pm 1$ & 3 \\
\cline { 2 - 6 } & 4-stack & $6.3 \pm 0.6$ & $138 \pm 9$ & $56 \pm 4$ & 2.5 \\
\hline \multirow{7}{*}{ Series } & 5-stack & $5.8 \pm 0.9$ & $115 \pm 7$ & $76 \pm 6$ & 1.5 \\
\cline { 2 - 6 } & 1-stack & $8.4 \pm 0.8$ & $158 \pm 2$ & $16 \pm 1$ & 9 \\
\cline { 2 - 6 } & 2-stack & $6.2 \pm 1.2$ & $209 \pm 7$ & $17 \pm 1$ & 12 \\
\hline & 3-stack & $4.8 \pm 0.2$ & $313 \pm 1$ & $14 \pm 1$ & 22 \\
\hline & 4-stack & $4.1 \pm 0.3$ & $342 \pm 5$ & $14 \pm 0$ & 24 \\
\hline
\end{tabular}

Nevertheless, unlike the series stack, the parallel stack did perform as expected and demonstrated a successful parallel connection. The maximum power density (and the voltage recorded at peak power) of the 5-stack was consistent with the averaged individual stack's maximum power densities (reported in Table 3.1). Additionally, the parallel configuration lowered the internal resistance of the stack while the voltage was maintained between each individual cell unit. This suggests that there were no significant energy losses from the parallel connection, and by stacking the cells in parallel, the peak power could be produced at relatively high current densities. 


\subsubsection{Stability}

Both the series and parallel 5-stack were further examined at their optimum resistance for over 45 cycles to analyze the stability of the stacks. While the parallel stack generally showed good stability with repeatable cell voltages and instantaneous power densities, the series stack showed a visible decrease in both parameters (Figure 3.8). The peak power density of the parallel 5-stack was around $5.8 \mathrm{~W} / \mathrm{m}^{2}$ with a voltage of $0.12 \pm 0.02$ at a resistance of only $1.5 \Omega$, whereas the peak power density of the series 5 -stack was about $3.7 \mathrm{~W} / \mathrm{m}^{2}$ with a voltage of $0.40 \pm 0.05$ at a resistance of $32 \Omega$. The peak power density and voltage for the 5-stack in series began decreasing around cycle 34 . 

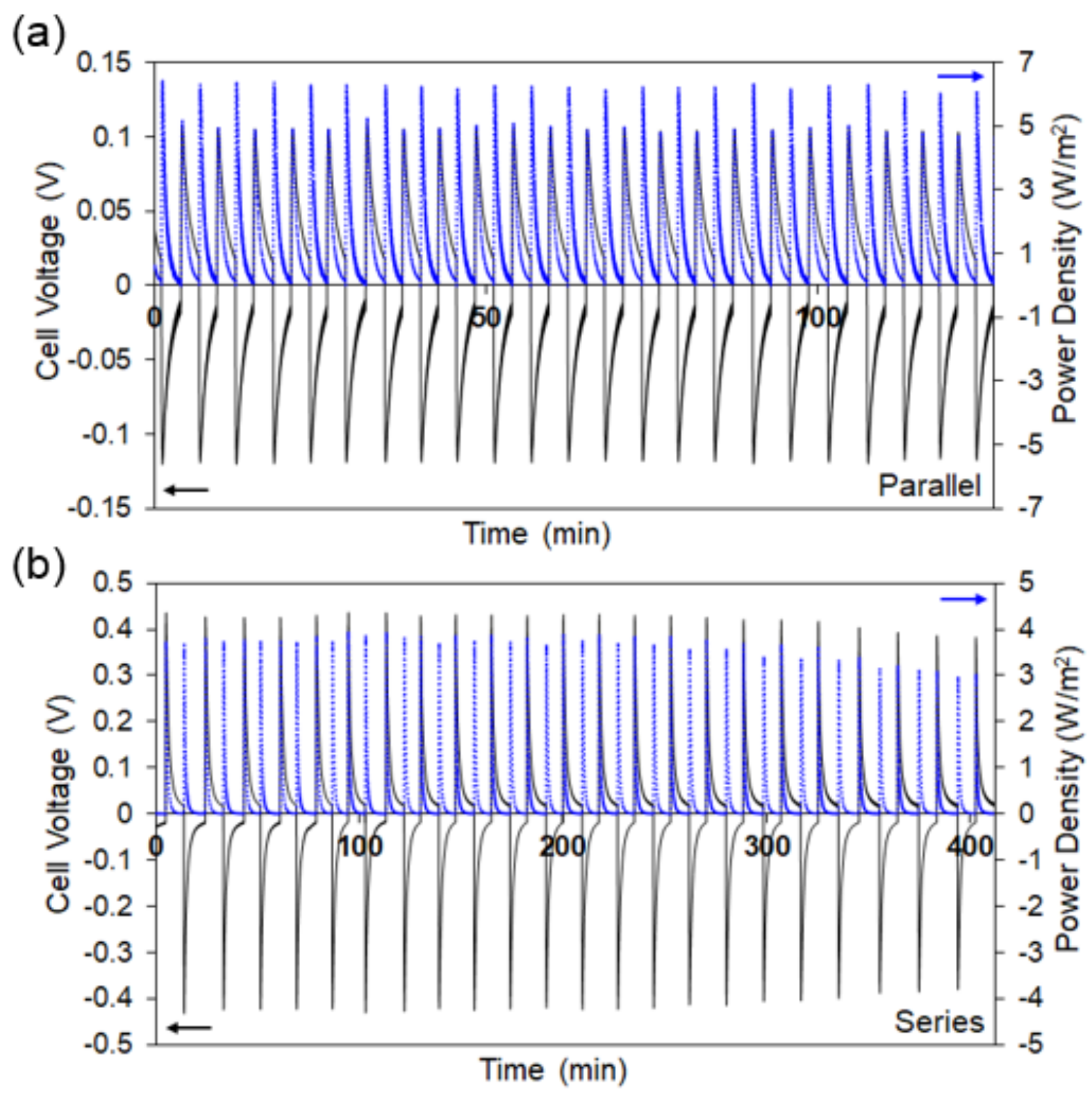

Figure 3.8. Power density and cell voltage for stacks 1-5 connected in (a) parallel and (b) series.

When the individual cycles for the parallel and series stacks were compared, it can be observed that the parallel stack successfully completed two cycles before the series stack finished one (Figure 3.9). Therefore, to complete 45 cycles during the stability analysis, the series stack required over 400 minutes whereas the parallel stack only required close to 125 minutes. The longer cycle times for the series stack, which resulted from the increased resistance of the stack, would have led to partial dissolution of the $\mathrm{CuHCF}$ electrodes [30]. The partial dissolution of the 
electrodes would in turn decrease in voltage and power density for the series stack, and thus decrease the stability in the power output of the stack.

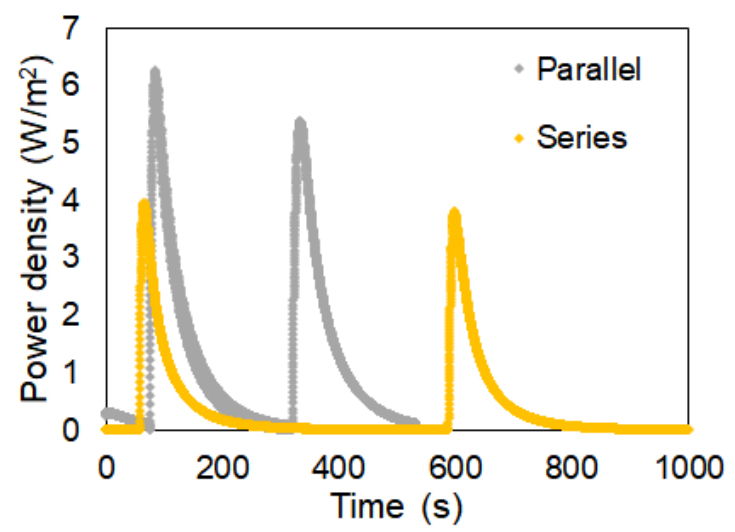

Figure 3.9. Power density for stacks 1-5 connected in parallel and series.

Additionally, because the high resistances at the larger stack sizes in series led to lengthy cycle times, a cutoff power of $0.25 \mathrm{~mW}$ was used (rather than a cutoff voltage) when calculating the average power for all stacks. For the parallel stack, the average power density for the first 10 cycles (out of 45) was $1.52 \pm 0.11 \mathrm{~W} / \mathrm{m}^{2}$, and $1.50 \pm 0.02 \mathrm{~W} / \mathrm{m}^{2}$ for the last 10 cycles. For the first and last 10 cycles of the series stack, the average power density was $1.15 \pm 0.03 \mathrm{~W} / \mathrm{m}^{2}$ and $1.01 \pm$ $0.04 \mathrm{~W} / \mathrm{m}^{2}$, respectively. Both configurations were not able to maintain a stable value throughout the repeated cycling, however the change in the average power density for the parallel stack was far less when compared to the series stack (Figure 3.10). In addition, a slight variation in the average power density can be observed between cycles for the parallel stack, however this variation is maintained consistently during the analysis. Therefore it can be assumed that when the HC and LC were being fed through the two different inlets, the electrodes and/or membranes that were positioned to receive the $\mathrm{HC}$ at one inlet were performing noticeably better than those positioned to receive the other inlet. 


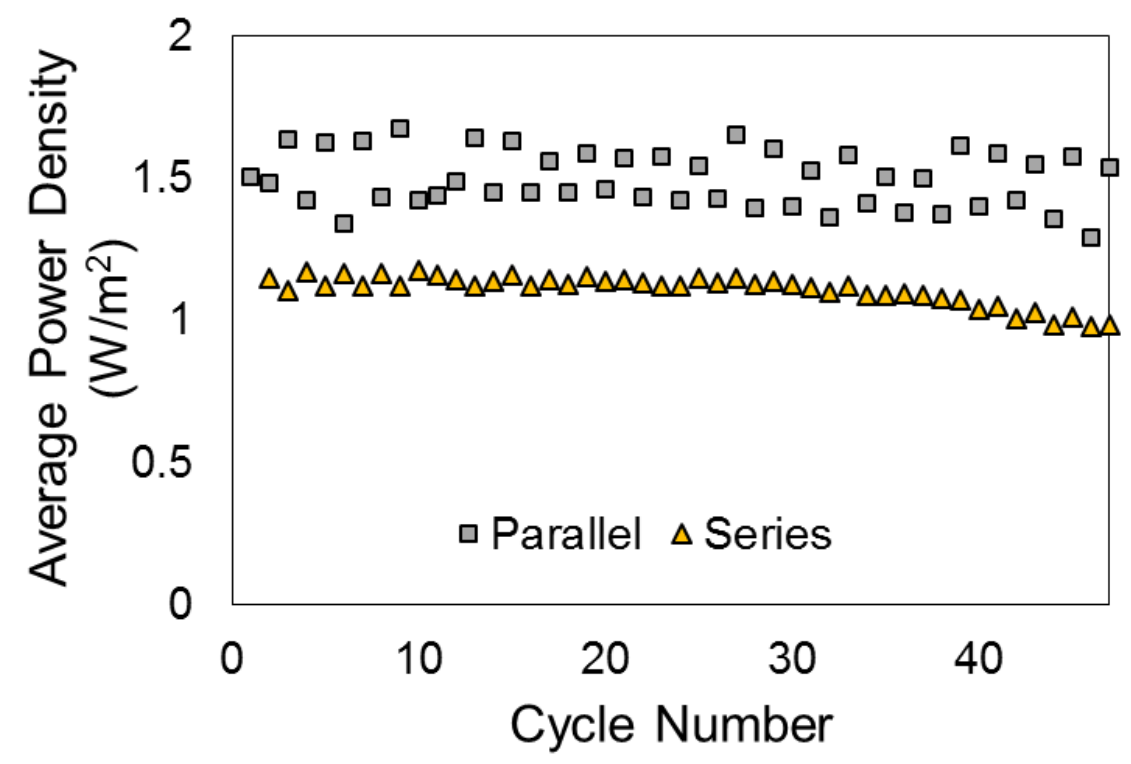

Figure 3.10. Average power densities and of the 5 -stack in parallel (squares) and series (triangles) under optimum external resistances of $1.5 \Omega$ (parallel) and $32 \Omega$ (series) (cutoff voltage $=8 \mathrm{mV}$, cycle cutoff power $=0.25 \mathrm{~mW})$.

A similar trend was observed for the energy density of both stacks (Figure 3.11). The energy density of the parallel stack was $253 \pm 11 \mathrm{~J} / \mathrm{m}^{2}$ for the first 10 cycles and $248 \pm 11 \mathrm{~J} / \mathrm{m}^{2}$ for the last 10 cycles, while the series stack had an energy density of $176 \pm 10 \mathrm{~J} / \mathrm{m}^{2}$ for the first 10 cycles and $145 \pm 15 \mathrm{~J} / \mathrm{m}^{2}$ for the last 10 cycles. These results demonstrate the superiority of the parallel stack; not only was the power and energy density of the parallel stack significantly higher than the series stack, but the severe decline that was observed during the last cycles of the series stack was avoided when the stack was wired in parallel. 


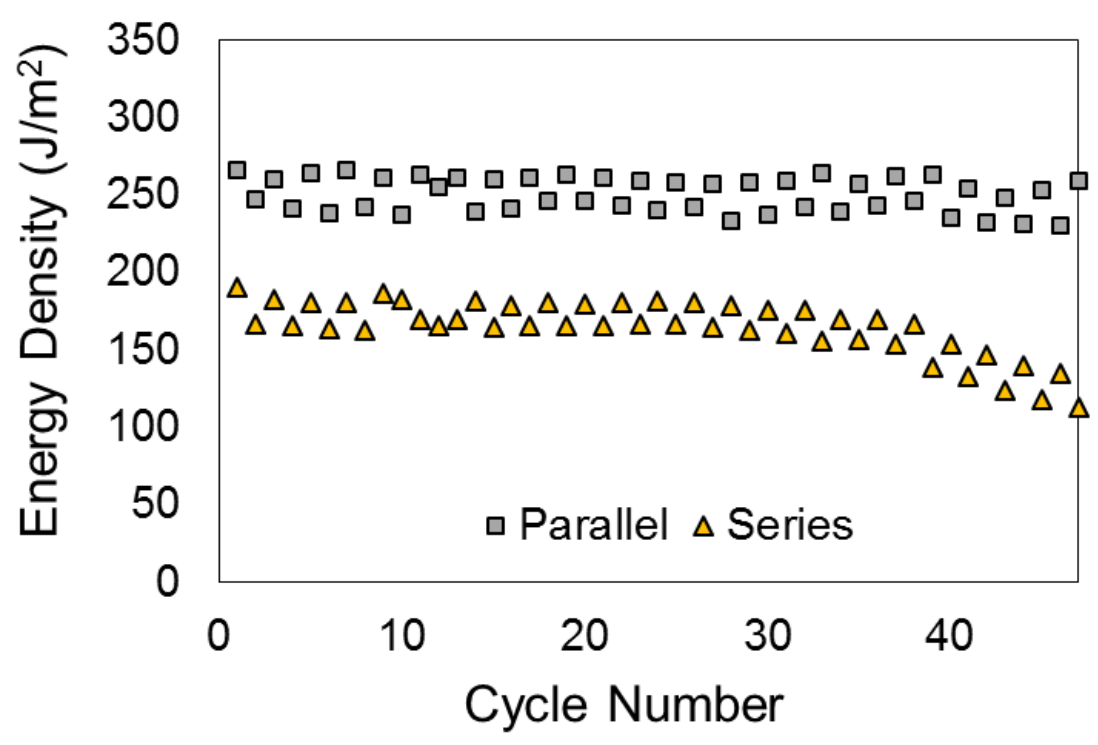

Figure 3.11. Energy densities of the 5-stack in parallel (squares) and series (triangles) under optimum external resistances of $1.5 \Omega$ (parallel) and $32 \Omega$ (series) (cutoff voltage $=8 \mathrm{mV}$, cycle cutoff power $=0.25 \mathrm{~mW}$ ). 


\section{CONCLUSIONS}

The power output of CFC stacks successfully increased with an increase in size for both the parallel $(8.6 \mathrm{~mW})$ and series $(5.6 \mathrm{~mW})$ configurations (compared to $2.7 \mathrm{~mW}$ for the single cell unit). The power density of both the parallel $\left(5.8 \mathrm{~W} \mathrm{~m}^{-2}\right.$ for 5 -stack) and series $\left(3.7 \mathrm{~W} \mathrm{~m}^{-2}\right.$ for 5 stack) stacks could not compare to that of the single cell unit $\left(8.9 \mathrm{~W} \mathrm{~m}^{-2}\right)$ as a result of the mixing of the feed solutions towards the back of the cell. This mixing was a direct consequence of the serial hydraulic flow design.

Recent work has estimated that electricity from salinity gradient technologies that use stacked membranes (i.e, RED) would be competitive against conventional renewable technologies if they could produce a power density of $2.7 \mathrm{~W} \mathrm{~m}^{-2}$ [29]. The average power density of the stacked cells for both the parallel and series wire configurations (stacks 2-5) were less than this value, whereas the average power density of the individual cell (stack 1) was higher (ca. $3.4 \mathrm{~W} \mathrm{~m}^{-2}$ ). These results suggest that the stack design used in this study could ultimately increase the capital costs when considering real-world applications. Furthermore, the operational costs should also be considered as well as any additional constraints that may arise from using real seawater.

In order to efficiently reduce costs in the flow cell stack, maintaining the performance of the single cell throughout the entire stack during operation is crucial. Different flow designs inside the stack could be considered as an alternative to the serial hydraulic flow design used here. For example a parallel flow design in which independent feed sources are used for each individual cell unit could limit the potential for mixing along the hydraulic path. It should be considered however that this would likely result in an uneven flow distribution throughout the stack, or a significantly higher required pumping energy. A similar but less significant depletion in solution concentration may also occur, which in turn could lower the power densities of all cells rather than just the cells 
in the back of the stack. Alternatively, cell units could be designed with modified sizes along the cascade. By strategically sizing the flow channels so that the local hydraulic residence times in different cells are varied, a more uniform power could be maintained despite the inevitable change of the electrostatic potentials in the feed solution. This application of various sized cells in a hydraulically connected cascade configuration has proven to successfully maintain the performance of a single cell throughout a Microbial Fuel Cell stack [48].

Additionally, the results of this study proved that the parallel wire configuration was more successful in the CFC stack than the series. The series stack exhibited severe performance degradation as the result of ionic cross-conduction which adversely effected the cell voltages and power output. The effect of the ionic cross-conduction (parasitic current) can be reduced by increasing the separation distance between cells as demonstrated in both microbial fuel cell (MFC) stacks and proton exchange membrane (PEM) fuel cell stacks [44,45,49,53]. Nevertheless, a larger separation may not entirely eliminate the negative effects of the cross-conduction when the cells were still hydraulically connected. Alternatively, insulating the stack by fluidically isolating each cell so that the electrolyte in each unit is separated has been reported to completely eliminate crossconduction in an MFC stack [54]. To determine whether this is a viable option for optimizing performance in the CFC stack, further analysis with a potential reconfiguration or different design may be needed.

These results highlight the importance of appropriate stack design and electrical connection, and the need for further design considerations for feasible and economical scale-up. Future work should focus on controlling or minimizing the mixing towards the back of the stack, and eliminating the parasitic current so that the performance of the series stack can be improved. If this 
can be accomplished, a combination of both the parallel and series electrical connections could be utilized to increase both the current and the voltage in the stack. 


\section{REFERENCES}

[1] Koseoglu, H.; Guler, E.; Harman, B. I.; Gonulsuz, E., Chapter 2 - Water Flux and Reverse Salt Flux. In Membrane-Based Salinity Gradient Processes for Water Treatment and Power Generation, Sarp, S.; Hilal, N., Eds. Elsevier: 2018; pp 57-86.

[2] Elimelech, M.; Phillip, W. A., The Future of Seawater Desalination: Energy, Technology, and the Environment. Science 2011, 333 (6043), 712-717.

[3] Alvarez-Silva, O; Osorio, A.; Winter, C., Practical global salinity gradient energy potential. Renewable and Sustainable Energy Reviews 2016, 60, 1387-1395.

[4] Lefebvre, O.; Moletta, R., Treatment of organic pollution in industrial saline wastewater: A literature review. Water Research 2006, 40 (20), 3671-3682.

[5] Achilli, A.; Prante, J. L.; Hancock, N. T.; Maxwell, E. B.; Childress, A. E., Experimental results from RO-PRO: a next generation system for low-energy desalination. Environmental Science \& Technology 2014, 48 (11), 6437-6443.

[6] Loeb, S., Energy production at the Dead Sea by pressure-retarded osmosis: challenge or chimera? Desalination 1998, 120 (3), 247-262.

[7] Loeb, S., One hundred and thirty benign and renewable megawatts from Great Salt Lake? The possibilities of hydroelectric power by pressure-retarded osmosis. Desalination 2001, 141 (1), 85-91.

[8] Lopez, A. M.; Dunsworth, H.; Hestekin, J. A., Reduction of the shadow spacer effect using reverse electrodeionization and its applications in water recycling for hydraulic fracturing operations. Separation and Purification Technology 2016, 162, 84-90.

[9] Thorsen, T.; Holt, T., The potential for power production from salinity gradients by pressure retarded osmosis. Journal of Membrane Science 2009, 335 (1), 103-110.

[10] Achilli, A.; Childress, A. E., Pressure retarded osmosis: from the vision of Sidney Loeb to the first prototype installation. Desalination 2010, 261, (3), 205-211.

[11] Loeb, S.; Norman, R. S., Osmotic power plants. Science 1975, 189 (4203), 654.

[12] Yip, N. Y.; Tiraferri, A.; Phillip, W. A.; Schiffman, J. D.; Hoover, L. A.; Kim, Y. C.; Elimelech, M., Thin-film composite pressure retarded osmosis membranes for sustainable power generation from salinity gradients.

[13] Straub, A. P.; Yip, N. Y.; Elimelech, M., Raising the bar: increased hydraulic pressure allows unprecedented high power densities in pressure-retarded osmosis. Environmental Science \& Technology Letters 2013, 1, (1), 55-59. 
[14] Maisonneuve, J.; Laflamme, C. B.; Pillay, P., Experimental investigation of pressure retarded osmosis for renewable energy conversion: Towards increased net power. Applied Energy 2016, 164, 425-435.

[15] Kim, D. I.; Kim, J.; Shon, H. K.; Hong, S., Pressure retarded osmosis (PRO) for integrating seawater desalination and wastewater reclamation: energy consumption and fouling. J. Membr. Sci. 2015, 483, 34-41.

[16] Mi, B.; Elimelech, M., Chemical and physical aspects of organic fouling of forward osmosis membranes. Journal of Membrane Science 2008, 320 (1), 292-302.

[17] Bar-Zeev, E.; Perreault, F.; Straub, A. P.; Elimelech, M., Impaired performance of pressure-retarded osmosis due to irreversible biofouling. Environ. Sci. Technol. 2015, 49, (21), 13050-13058.

[18] Weinstein, J. N.; Leitz, F. B., Electric power from differences in salinity: the dialytic battery. Science 1976, 191 (4227), 557.

[19] Post, J. W.; Hamelers, H. V. M.; Buisman, C. J. N., Energy recovery from controlled mixing salt and fresh water with a reverse electrodialysis system. Environmental Science \& Technology 2008, 42 (15), 5785-5790.

[20] Vermaas, D. A.; Saakes, M.; Nijmeijer, K., Doubled power density from salinity gradients at reduced intermembrane distance. Environmental Science \& Technology 2011, 45 (16), 70897095 .

[21] Moreno, J.; Slouwerhof, E.; Vermaas, D. A.; Saakes, M.; Nijmeijer, K., The Breathing Cell: cyclic intermembrane distance variation in reverse electrodialysis. Environmental Science \& Technology 2016, 50 (20), 11386-11393.

[22] Ramon, G. Z.; Feinberg, B. J.; Hoek, E. M. V., Membrane-based production of salinitygradient power. Energy \& Environmental Science 2011, 4 (11), 4423-4434.

[23] Brogioli, D., Extracting renewable energy from a salinity difference using a capacitor. Phys. Rev. Lett. 2009, 103, (5), 058501.

[24] Brogioli, D.; Ziano, R.; Rica, R. A.; Salerno, D.; Kozynchenko, O.; Hamelers, H. V. M.; Mantegazza, F., Exploiting the spontaneous potential of the electrodes used in the capacitive mixing technique for the extraction of energy from salinity difference. Energy Environ. Sci. 2012, 5, (12), 9870 .

[25] Hatzell, M. C.; Cusick, R. D.; Logan, B. E., Capacitive mixing power production from salinity gradient energy enhanced through exoelectrogen-generated ionic currents. Energy Environ. Sci. 2014, 7, (3), 1159-1165.

[26] Liu, F.; Schaetzle, O.; Sales, B. B.; Saakes, M.; Buisman, C. J. N.; Hamelers, H. V. M., Effect of additional charging and current density on the performance of Capacitive energy extraction based on Donnan Potential. Energy Environ. Sci. 2012, 5, (9), 8642. 
[27] Sales, B. B.; Saakes, M.; Post, J. W.; Buisman, C. J.; Biesheuvel, P. M.; Hamelers, H. V., Direct power production from a water salinity difference in a membrane-modified supercapacitor flow cell. Environ. Sci. Technol. 2010, 44, (14), 5661-5.

[28] La Mantia, F.; Pasta, M.; Deshazer, H. D.; Logan, B. E.; Cui, Y., Batteries for Efficient Energy Extraction from a Water Salinity Difference. Nano Letters 2011, 11 (4), 1810-1813.

[29] Kim, T.; Logan, B. E.; Gorski, C. A., High power densities created from salinity differences by combining electrode and Donnan potentials in a concentration flow cell. Energy \& Environmental Science 2017, 10 (4), 1003-1012.

[30]. Zhu, X.; Xu, W.; Tan, G.; Wang, Y., Concentration Flow Cells for Efficient Salinity Gradient Energy Recovery with Nanostructured Open Framework Hexacyanoferrate Electrodes. ChemistrySelect 2018, 3, 5571.

[31] Tan, G.; Li, H.; Zhu, H.; Lu, S.; Fan, J.; Li, G.; Zhu, X., Concentration Flow Cells Based on Chloride-Ion Extraction and Insertion with Metal Chloride Electrodes for Efficient Salinity Gradient Energy Harvest. ACS Sustainable Chemistry \& Engineering 2018, 6 (11), 1521215218.

[32] Zhu, H.; Xu, W.; Tan, G.; Whiddon, E.; Wang, Y.; Arges, C. G.; Zhu, X., Carbonized peat moss electrodes for efficient salinity gradient energy recovery in a capacitive concentration flow cell. Electrochimica Acta 2019, 294, 240-248.

[33] Murphy, O. J.; Cisar, A.; Clarke, E., Low-cost light weight high power density PEM fuel cell stack. Electrochimica Acta 1998, 43 (24), 3829-3840.

[34] Aelterman, P.; Rabaey, K.; Pham, H.T.; Boon, N.; Verstraete, W., Continuous electricity generation at high voltages and currents using stacked microbial fuel cells. Environ. Sci. Technol. 2006, 40, (10), 3388-3394.

[35] Li, X.; Zhang, H.; Mai, Z.; Zhang, H.; Vankelecom, I., Ion exchange membranes for vanadium redox flow battery (VRB) applications. Energy \& Environmental Science 2011, 4 (4), $1147-1160$.

[36] Larminie, J.; Dicks, A. Fuel Cell Systems Explained; John Wiley \& Sons: Chichester, UK, 2000 .

[37] He, W.; Wallack, M. J.; Kim, K.-Y.; Zhang, X.; Yang, W.; Zhu, X.; Feng, Y.; Logan, B. E., The effect of flow modes and electrode combinations on the performance of a multiple module microbial fuel cell installed at wastewater treatment plant. Water Research 2016, 105, 351-360.

[38] Wessells, C. D.; Peddada, S. V.; McDowell, M. T.; Huggins, R. A.; Cui, Y., The effect of insertion species on nanostructured open framework hexacyanoferrate. Battery Electrodes 2012.

[39] Liu, S.; Pan, G. L.; Li, G. R.; Gao, X. P., Copper hexacyanoferrate nanoparticles as cathode material for aqueous Al-ion batteries. Journal of Materials Chemistry A 2015, 3 (3), 959-962. 
[40] Walter, X. A.; Forbes, S.; Greenman, J.; Ieropoulos, I. A., From single MFC to cascade configuration: The relationship between size, hydraulic retention time and power density. Sustainable Energy Technologies and Assessments 2016, 14, 74-79.

[41] O’Hayre, R.; Fabian, T.; Lee, S.; Prinz, F., Lateral ionic conduction in planar array fuel cells. Journal of The Electrochemical Society 2003, 150, A430.

[42] Aelterman, P.; Rabaey, K.; Pham, H.T.; Boon, N.; Verstraete, W., Continuous electricity generation at high voltages and currents using stacked microbial fuel cells. Environ. Sci.

Technol. 2006, 40, (10), 3388-3394.

[43] Wang, B.; Han, J.-I., A single chamber stackable microbial fuel cell with air cathode.

Biotechnol. Lett. 2009, 31 (3), 387-393.

[44] Zhuang, L., Zhou, S., Substrate cross-conduction effect on the performance of serially connected microbial fuel cell stack. Electrochem. Commun. 2009, 11 (5), 937-940.

[45] Winfield, J.; Ieropoulos, I.; Greenman, J.; Dennis, J., Investigating the effects of fluidic connection between microbial fuel cells. Bioprocess Biosyst. Eng. 2011, 34 (4), 477-484.

[46] Zhuang, L., Zheng, Y., Zhou, S., Yuan, Y., Yuan, H., Chen, Y., Scalable microbial fuel cell (MFC) stack for continuous real wastewater treatment. Bioresour. Technol. 2012, 106, 82-88.

[47] Veerman, J.; Post, J. W.; Saakes, M.; Metz, S. J.; Harmsen, G. J., Reducing power losses caused by ionic shortcut currents in reverse electrodialysis stacks by a validated model. Journal of Membrane Science 2008, 310 (1), 418-430.

[48] Oh, S. E.; Logan, B. E., Voltage reversal during microbial fuel cell stack operation. Journal of Power Sources 2007, 167 (1), 11-17.

[49] An, J.; Lee, H.-S., Occurrence and implications of voltage reversal in stacked microbial fuel cells. ChemSusChem 2014, 7 (6), 1689-1695.

[50] Taniguchi, A.; Akita, T.; Yasuda, K.; Miyazaki, Y., Analysis of electrocatalyst degradation in PEMFC caused by cell reversal during fuel starvation. Journal of Power Sources 2004, 130 (1), 42-49.

[51] Aelterman, P.; Rabaey, K.; Pham, H. T.; Boon, N.; Verstraete, W., Continuous electricity generation at high voltages and currents using stacked microbial fuel cells. Environmental Science \& Technology 2006, 40 (10), 3388-3394.

[52] An, J.; Sim, J.; Lee, H.-S., Control of voltage reversal in serially stacked microbial fuel cells through manipulating current: Significance of critical current density. Journal of Power Sources 2015, 283, 19-23.

[53] Kim, D.; An, J.; Kim, B.; Jang, J.K.; Kim, B.H.; Chang, I.S., Scaling-up microbial fuel cells: configuration and potential drop phenomenon at series connection of unit cells in shared anolyte. ChemSusChem 2012, 5 (6), 1086-1091. 
[54] Ledezma, P.; Greenman, J.; Ieropoulos, I., MFC-cascade stacks maximise COD reduction and avoid voltage reversal under adverse conditions. Bioresource Technology 2013, 134, 158165 . 


\section{VITA}

Elizabeth received her bachelor's degree in Earth and Environmental Sciences from the University of Michigan (Ann Arbor) in 2015. Upon graduating she moved to Boulder, Colorado to work at the United States Geology Survey (USGS). In 2017 she received the Louisiana Board of Regents Fellowship to complete her master's in the Department of Civil and Environmental Engineering at Louisiana State University. 